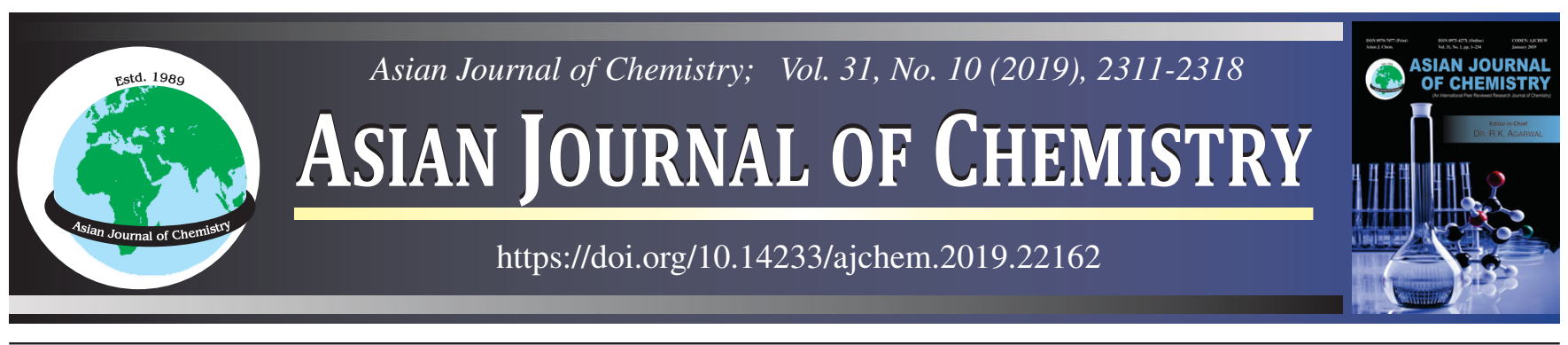

\title{
Design, Synthesis, Characterization and Antiproliferative Activities of Ru(II) Complexes of Substituted Benzimidazoles
}

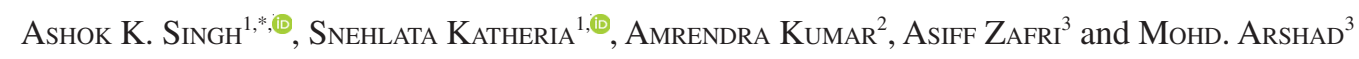

${ }^{1}$ Department of Chemistry, University of Lucknow, Lucknow-226007, India

${ }^{2}$ Department of Physics, University of Lucknow, Lucknow-226007, India

${ }^{3}$ Department of Zoology, University of Lucknow, Lucknow-226007, India

*Corresponding author: E-mail: singhaks3@ @rediffmail.com

Received: 29 April 2019;

Accepted: 31 May 2019;

Published online: 30 August 2019;

AJC-19542

Synthesis of $\left[\mathrm{Ru}\left(\mathrm{PPh}_{3}\right)_{2}(\mathrm{BZM})_{2} \mathrm{Cl}_{2}\right](\mathrm{BZM}=\mathrm{LS} 1, \mathrm{LS} 2, \mathrm{LS} 3, \mathrm{LS} 4$ and LS5) where LS1 = (1H-benzo[d]imidazole-2-yl)methanethiol, LS2 = 2-(4-bromobutyl)-1H-benzo[d]imidazole, LS3 = 2-(4-nitrophenyl)-1H-benzo[d]imidazole, LS4 = 2-(4-chlorophenyl)-1Hbenzo $[d]$ imidazole and LS5=4-(1H-benzo $[d]$ imidazol-2-yl)aniline $\left(\mathrm{BZM}=\right.$ benzimidazoles, $\mathrm{PPh}_{3}=$ triphenylphosphine $)$ and metal complexes as MR, [Ru $\left.\left(\mathrm{PPh}_{3}\right)_{4} \mathrm{Cl}_{2}\right]$, MLS1, MLS2, MLS3, MLS4 and MLS5 for use as potential anticancer compounds have been investigated. The complexes have been characterized by elemental analysis, IR, multinuclear NMR, UV-visible and ESI-MS spectroscopic techniques. The geometries of all complexes have been optimized by using density functional theory (DFT). The cytotoxicity effects of MR, MLS2 and LS1 were also investigated on Human cervical carcinoma cells (HeLa) by MTT assay, ROS generation and nuclear apoptosis assay. The percent cell viability assessed by MTT assay suggested that the synthesized MR, MLS2 and LS1 significantly reduce the viability of HeLa cells, in a dose-dependent manner. The inhibitory concentration (IC 50 ) of MR, MLS2 and LS1 against HeLa cells was found $90.8,81.8$ and $115 \mu \mathrm{M}$, respectively. These compounds also induced the over production of intracellular reactive oxygen species (ROS) as well as the condensed and fragmented nucleus, which supports the molecular mechanism of cell death by apoptosis. The investigations suggested that the compounds MR, MLS2 and LS1 induce the cell death in HeLa cells through apoptotic pathway.

Keywords: Ruthenium(II) complex, Benzimidazoles, Apoptosis, Cytotoxicity effect.

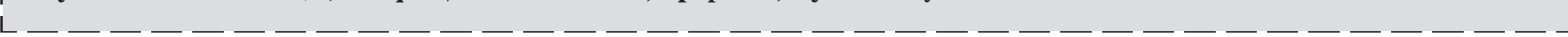

\section{INTRODUCTION}

Platinum complexes attracted researcher's interests due to its promising anticancer properties, because they are still the most successful medical therapeutic metallodrugs [1,2]. Due to the serious side effects of platinum drugs, we encouraged the development of anticancer agents on the basis of other metals with low side effects. In this direction, ruthenium compounds also represent a promising metal-based anticancer complex that can offer less toxicity than platinum based drugs [3]. It demonstrated some exciting antitumor properties and this may be the alternative option to platinum based antitumor medicines. Additionally, ruthenium has the ability to mimic iron cation binding to certain molecules, in view of rate of ligand exchange and accessible oxidation states [4]. Further, imidazole ligand shows imperative role with ruthenium to target site recog- nition against ovarian carcinoma cells [5]. In particular, some ruthenium derivative have been screened for their antineoplastic activity and their derivative $\left[\mathrm{H}_{2} \mathrm{Im}\right]\left[\right.$ trans- $\mathrm{Ru}(\mathrm{III}) \mathrm{Cl}_{4}$ (DMSO$\mathrm{S})(\mathrm{HIm})]$ (NAMI-A) and imidazolium trans-[transchlorobis $(1 \mathrm{H}$ indazole)-ruthenate(III)] (KP1019 or FFC14A) were the first ruthenium based anticancer complexes that have been entered into clinical trials [6,7]. Further, the ruthenium complexes comprising of chalcones and flavones will be possible drugs against breast cancer $[8,9]$. Since the toxicity of many drugs used in chemotherapy limits their clinical sources, subsequently analyzed the cytotoxic activity of the compounds using MTT assay [10].

The potential of different metal based anticancer agent have been widely explored and especially ruthenium complexes have been extensively studied in drug discovery [11]. The drug resistance developed by cisplatin against cancer cells, have led to new line of approach for development of new ruthenium

This is an open access journal, and articles are distributed under the terms of the Attribution 4.0 International (CC BY 4.0) License. This license lets others distribute, remix, tweak, and build upon your work, even commercially, as long as they credit the author for the original creation. You must give appropriate credit, provide a link to the license, and indicate if changes were made. 
complexes for metal based drug that can be used in the fields of chemotherapy. In general, the drug discovery approach targets the DNA or cellular mechanism [12]. Therefore, the interaction of ruthenium complexes to adenine, guanine and cytosine, through weak interaction and hydrogen bonding, signifying the possibility to design compounds to interact through nucleotides [12]. The binding modes and affinity of ruthenium complexes also depends on the structure of DNA [13]. In this respect, we have synthesized ruthenium complexes containing a triphenylphosphine and substituted benzimidazole and assessed their interaction with human cervical carcinoma cells. The cytotoxicity of the complexes was assessed using cancer and normal cell lines in vitro conditions.

\section{EXPERIMENTAL}

The reagent and chemicals used for synthesis were procured from Sigma Aldrich, Hi-media and Merck and used without further purification. Column chromatography of all the synthesized compounds was performed by silica gel 60 (40-60 Merck, India) as stationary phase and acetonitrile as an eluent. FT-IR spectra were recorded in $\mathrm{KBr}$ pellets on Perkin Elmer AC-1C spectrometer from 4000 to $450 \mathrm{~cm}^{-1}$. ${ }^{1} \mathrm{H}$ NMR spectra were recorded in DMSO- $d_{6}$ on Bruker Avance III HD spectrometer at $300 \mathrm{MHz}$ using TMS as an internal reference. ESI-MS mass spectra were recorded on JEOL SX 102/DA-6000 spectrometer. Elemental analysis was performed on Exeter analytical INC Model CE-440 C H N ANALYSER. Electronic absorption spectra were recorded on Labtronic 2900 UV-Vis spectrophotometer and conductivity is carried out on microprocessor based conductivity/TDS meter ESICO Model 1601.

\section{in vitro Cytotoxicity activity studies}

Cervical carcinoma cell line (HeLa) culture: The cell line of human cervix carcinoma (HeLa) was procured from the National Centre for Cell Sciences (NCCS), Pune, India. The cell was cultured at $37{ }^{\circ} \mathrm{C}$ humidified condition and $5 \% \mathrm{CO}_{2}$ in MEM (E) culture media. The medium was supplemented with $10 \%$ fetal bovine serum (FBS), $1 \%$ antibiotic solution $(10,000 \mathrm{U} / \mathrm{mL}$ penicillin and $10 \mathrm{mg} / \mathrm{mL}$ streptomycin), $0.1 \mathrm{mM}$ non-essential amino acids, $2.0 \mathrm{mM}$ L-glutamine, $1.0 \mathrm{mM}$ sodium pyruvate and $1.5 \mathrm{~g} / \mathrm{L} \mathrm{NaHCO}$.

Cell viability assay on HeLa cells: HeLa cells $\left(1 \times 10^{4}\right.$ cells per $\mathrm{mL}$ ) were seeded in $100 \mu \mathrm{L}$ MEM (E) media per well in 96 well titer plate for $24 \mathrm{~h}$ at $37^{\circ} \mathrm{C}$ and $5 \% \mathrm{CO}_{2}$ as per previous protocol [13]. The treatment was conducted for $24 \mathrm{~h}$ incubation with various concentrations $(10,25,50,100$ and $200 \mu \mathrm{M}$ ) of the MR, MLS2 and LS1. Afterwards, $20 \mu \mathrm{L}$ of MTT reagent was added to each well and kept for $4 \mathrm{~h}$ at $37^{\circ} \mathrm{C}$ until the development of formazan crystals. Subsequently, the obtained formazan crystals were solubilized in $100 \mu \mathrm{L}$ of DMSO and the absorbance was recorded at $540 \mathrm{~nm}$ using a microplate reader (BIORAD-680). The \% cell viability has been presented as a ratio of absorbance of treated groups to the absorbance of control cells (without treatment). The \% cell viability was calculated following the given equation:

$$
\text { Cell viability }(\%)=\frac{\mathrm{A}_{540}(\text { treated cells })}{\mathrm{A}_{540}(\text { control cells })} \times 100
$$

Cellular morphology studies in HeLa cells: The morphological changes in HeLa cells, treated with MR, MLS2 and LS1 were examined under the inverted contrast-phase microscope. Briefly, HeLa cells was plated in 48 well culture plates and treated with 10, 25, 50, 100 and $200 \mu \mathrm{M}$ concentrations of MR, MLS2 and LS1 for $24 \mathrm{~h}$ of incubation. Thereafter, the cell morphology was examined by an inverted contrast-phase microscope and photographed [14].

Detection of ROS in HeLa cells: The intracellular ROS level was detected by DCFH-DA (2,7-dichlorodihydrofluoresce in diacetate) staining in accordance with the previous report [15]. The HeLa cells were first seeded at the density 1 $\times 10^{4}$ per well in a 96-well culture plate and incubated at 37 ${ }^{\circ} \mathrm{C}$ for $24 \mathrm{~h}$ in $5 \% \mathrm{CO}_{2}$. Then, cells were exposed to 25,50 and $100 \mu \mathrm{M}$ concentrations of MR, MLS2 and LS1 for $12 \mathrm{~h}$. Subsequently, for the fluorescence microscopy imaging, the cells were washed thrice with PBS (phosphate buffer saline) and then incubated with fluorescence agent DCFH-DA (10 $\mathrm{mM}$ ) for $25 \mathrm{~min}$ at $37^{\circ} \mathrm{C}$. Later, cells were washed with MEM (E) three times and were observed with a fluorescence inverted microscope (Nikon ECLIPSE Ti-S, Japan). For the quantitative analysis of ROS, HeLa cells $\left(1 \times 10^{4}\right.$ per well $)$ were seeded in 96-well black bottom titer plate and treated with 25, 50 and $100 \mu \mathrm{M}$ concentrations of the MR, MLS2 and LS1. Afterwards, cells were trypsinized and washed thrice with PBS, then incubated with DCFH-DA $(10 \mathrm{mM})$ for $25 \mathrm{~min}$. The cells were analyzed for the fluorescence intensity by a multiwall microplate reader (Synergy, BioTek) with an excitation and emission wavelength at 485 and $528 \mathrm{~nm}$, respectively. The values of fluorescence intensity were expressed as the percentage of the treated group with respect to the control group.

Analysis of nuclear apoptosis in HeLa cells: For the nuclear and chromatin structural change study, the HeLa cells were seeded in 96 well culture plate and then treated with different doses of MR, MLS2 and LS1 at 25, 50 and $100 \mu \mathrm{M}$ concentrations for $24 \mathrm{~h}$ [16]. Consequently, cells were washed thrice with PBS and fixed in $4 \%$ paraformaldehyde (used as a fixative) for $10 \mathrm{~min}$ and then permeabilized with permeabilizing buffer (4\% paraformaldehyde and $0.5 \%$ Triton X-100) and stained with $10 \mathrm{mM}$ of DAPI stain. After staining, cells were examined with the help of an inverted fluorescence microscope at the excitation wavelength of $360 \mathrm{~nm}$ and an emission wavelength of $454 \mathrm{~nm}$ (Nikon ECLIPSE Ti-S, Japan) [16]. For the quantitative analysis of apoptotic cells, the tests were performed thrice for every treatment group and the 100 cells per well were calculated in at least 10 random fields per well, to count the percent apoptotic cells using an inverted fluorescent microscope (Nikon ECLIPSE Ti-S, Japan).

Statistical analysis: The data on cell viability, nuclear condensation and ROS generation were represented as mean \pm standard error mean (SEM) from at least three independent studies. Determination of difference in between the experimental and the control groups was compared using one-way ANOVA followed by Dunnett's multiple range test of Graph Pad prism software (Version 5.01). The $p$ value of less than 0.05 was designated to be statistically significant.

General procedure for synthesis of ligands (LS1-LS5): All substituted benzimidazole ligands were prepared by the 
previously reported procedure [17]. $o$-Phenylenediamine $(0.25$ mol) and appropriate carboxylic acid $(0.34 \mathrm{~mol})$ was heated on an oil bath at $100^{\circ} \mathrm{C}$ for $8 \mathrm{~h}$. The completion of the reaction was monitored by TLC. After completion of the reaction, the reaction mixture was cooled and its $\mathrm{pH}$ was adjusted between 7-8 using $10 \% \mathrm{NaOH}$ solution. The crude benzimidazole was filtered and washed with ice-cold water. The crude product was dissolved in $40 \mathrm{~mL}$ of boiling water and $2 \mathrm{~g}$ of carbon was added and digested for $15 \mathrm{~min}$. The solution was filtered while hot, cooled the filtrate to about $10^{\circ} \mathrm{C}$. The pure product obtained was filtered, washed with $25 \mathrm{~mL}$ of cold water and dried (Scheme-I).

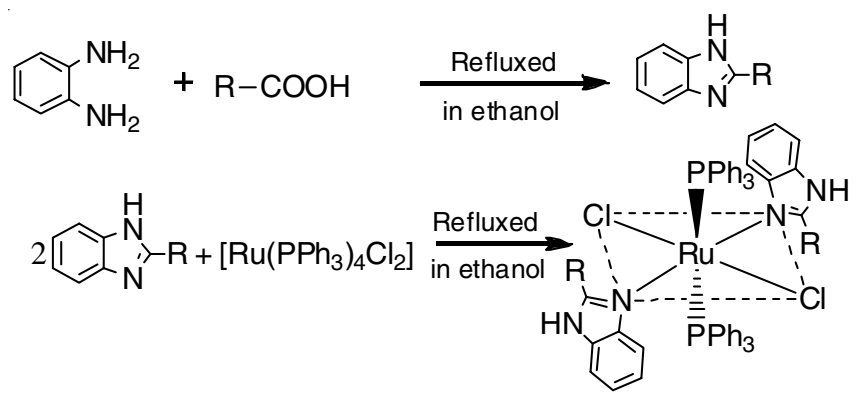

$\mathrm{R}=\mathrm{SH}(\mathrm{LS} 1), \mathrm{Br}(\mathrm{LS} 2), \mathrm{NO}_{2}$ (LS3), $\mathrm{Cl}$ (LS4), $\mathrm{NH}_{2}$ (LS5)

Scheme-I: Synthetic route for synthesis of ligand and its ruthenium(II) complexes

(1H-Benzo[d] imidazole-2-yl) methanethiol (LS1): Pale yellow solid; yield: $42.90 \%$, m.p.: $158^{\circ} \mathrm{C}$, IR $\left(\mathrm{KBr}, v_{\max }, \mathrm{cm}^{-1}\right)$ : 3445 (N-H str.), 2963 (Ar C-H), 2600 (S-H str.), 1700 (Ar-C), $1600(\mathrm{C}=\mathrm{N}), 2900(\mathrm{Ar} \mathrm{C}-\mathrm{H}) .{ }^{1} \mathrm{H}$ NMR $\left(300 \mathrm{MHz}, \mathrm{DMSO}-d_{6}, \delta\right.$ ppm): $\delta$ 7.01-7.51 (m, 4H Ar-H), $4.41(\mathrm{~s}, 1 \mathrm{H}, \mathrm{N}-\mathrm{H}), 2.01$ (s, $\left.2 \mathrm{H}, \mathrm{CH}_{2}\right), 2.2(\mathrm{~s} 1 \mathrm{H}, \mathrm{SH}) .{ }^{13} \mathrm{CNMR}\left(300 \mathrm{MHz}, \mathrm{DMSO}-d_{6}, \delta \mathrm{ppm}\right)$ : $133,132,122$, UV-Vis (DMSO, $\lambda_{\max }, \mathrm{nm}\left(\varepsilon_{\max } \times 10^{3} \mathrm{M}^{-1} \mathrm{~cm}^{-1}\right)$ : 250 (2.2), 300 (2.4), $348(0.1)$.

2-(4-Bromobutyl)-1H-benzo[d]imidazole (LS2): Reddish brown solid; yield: $40.4 \%$, m.p.: $166^{\circ} \mathrm{C}$, IR $\left(\mathrm{KBr}, v_{\max }, \mathrm{cm}^{-1}\right)$ : 3300 (N-H str.), 1527(C=N str.), 2900( ArH, C-H), 1700 (Ar $\mathrm{C}=\mathrm{C}) .{ }^{1} \mathrm{H}$ NMR $\left(300 \mathrm{MHz}, \mathrm{DMSO}-d_{6}, \delta \mathrm{ppm}\right): \delta 6.57-7.90$ (m, 8H, Ar-H), $6.96(\mathrm{~s}, 1 \mathrm{H}, \mathrm{N}-\mathrm{H}), 2.50-2.54\left(\mathrm{~m}, 8 \mathrm{H}, \mathrm{CH}_{2}\right) ;{ }^{13} \mathrm{C}$ NMR (300 MHz, DMSO- $d_{6}, \delta$ ppm): $\delta 146,142,141,136,133$, $128,126,123,121,118,115,101$. UV-Vis (DMSO, $\lambda_{\max }, \mathrm{nm}$ $\left(\varepsilon_{\max } \times 10^{3} \mathrm{M}^{-1} \mathrm{~cm}^{-1}\right): 240(0.9), 270(0.95), 275(0.8)$.

2-(4-Nitrophenyl)-1H-benzo[d]imidazole (LS3): Brown solid ; yield: $40.50 \%$, m.p.: $220^{\circ} \mathrm{C}$, IR $\left(\mathrm{KBr}, \nu_{\max }, \mathrm{cm}^{-1}\right): 3100$ (N-H str.), 3000 (Ar C-H), 1350 (N-O sym str.), 1400 (C-N str.), (C-Br), 1700 (C=C ring str.), 1602 ( $\mathrm{N}-\mathrm{O}$ asym str.), $1539(\mathrm{C}=\mathrm{N}$ str.). ${ }^{1} \mathrm{H}$ NMR (300 MHz, DMSO- $d_{6}, \delta$ ppm): $\delta 7.57-8.22(\mathrm{~m}$, $8 \mathrm{H}, \mathrm{Ar}-\mathrm{H}), 6.87$ (s, $1 \mathrm{H}, \mathrm{N}-\mathrm{H}) .{ }^{13} \mathrm{C}$ NMR $\left(300 \mathrm{MHz}, \mathrm{DMSO}-d_{6}\right.$, $\delta$ ppm): $\delta 167,150,146,141,138,137,131,128,126,124,101$. UV-Vis (DMSO, $\lambda_{\max }, \mathrm{nm}\left(\varepsilon_{\max } \times 10^{3} \mathrm{M}^{-1} \mathrm{~cm}^{-1}\right): 250(1.7), 340$ $(0.1), 450(0.5)$.

2-(4-Chlorophenyl)-1H-benzo[d]imidazole (LS4): Black colour solid; yield: $39.6 \%$, m.p. $234^{\circ} \mathrm{C}$, IR $\left(\mathrm{KBr}, v_{\max }, \mathrm{cm}^{-1}\right)$ : 3150(NH str.), $3000(\mathrm{ArH}),(\mathrm{C}-\mathrm{Cl}), 1525(\mathrm{C}=\mathrm{N}), 1600(\mathrm{C}=\mathrm{C}$ ring system), 1429 (C-N str.). ${ }^{1} \mathrm{H}$ NMR (300 MHz, DMSO- $d_{6}$, $\delta \mathrm{ppm}): \delta 7.52-8.12(\mathrm{~m}, 8 \mathrm{H}, \mathrm{Ar}-\mathrm{H}), 6.80(\mathrm{~s}, 1 \mathrm{H} \mathrm{N}-\mathrm{H}) .{ }^{13} \mathrm{C}$ NMR (300 MHz, DMSO- $d_{6}, \delta$ ppm): $\delta 165,149,145,141,138,130$, $128,126,123,101$. UV-Vis (DMSO, $\lambda_{\max }, \mathrm{nm}\left(\varepsilon_{\max } \times 10^{3} \mathrm{M}^{-1}\right.$ $\left.\mathrm{cm}^{-1}\right): 270$ (2.4), $360(0.1), 420(4.0)$.
4-(1H-Benzo[d]imidazol-2-yl)aniline (LS5): Brown colour solid; yield: $42.6 \%$; m.p.: $226^{\circ}$, IR $\left(\mathrm{KBr}, v_{\max }, \mathrm{cm}^{-1}\right) 3600(\mathrm{~N}-$ $\mathrm{H}$ str. $), 1450(\mathrm{C}=\mathrm{N}$ str. $), 1650$ (Ar-C=C), $2350\left(\mathrm{Ar} \mathrm{N}-\mathrm{H}\left(\mathrm{NH}_{2}\right)\right)$, 2900 (Ar C-H), 850 (Ar C-N). 'H NMR (300 MHz, DMSO$\left.d_{6}, \delta \mathrm{ppm}\right): \delta 6.40-7.89(\mathrm{~m}, 8 \mathrm{H}, \mathrm{Ar}-\mathrm{H}), 6.40(\mathrm{~s}, 1 \mathrm{H}, \mathrm{N}-\mathrm{H})$, $2.50\left(\mathrm{~s}, 2 \mathrm{H}, \mathrm{NH}_{2}\right) .{ }^{13} \mathrm{C}$ NMR $\left(300 \mathrm{MHz}, \mathrm{DMSO}-d_{6}, \delta \mathrm{ppm}\right): \delta$ $145,142,139,128,127,102$. UV-Vis (DMSO, $\lambda_{\max }, \mathrm{nm}\left(\varepsilon_{\max }\right.$ $\left.\times 10^{3} \mathrm{M}^{-1} \mathrm{~cm}^{-1}\right): 320(0.5), 420(4.0)$.

General procedure for synthesis of $\mathrm{Ru}(\mathrm{II})$ complexes: The ruthenium precursor was prepared in accordance with the previously reported method [18]. The precursor was synthesized with the reaction of ruthenium trichloride trihydrate with a methanolic solution of tryphinylphosphine in excess and refluxed for $8 \mathrm{~h}$ under nitrogen, which gives the black precipitate of $\left[\mathrm{RuCl}_{2}\left(\mathrm{PPh}_{3}\right)_{4}\right](\mathbf{M R})$, washed with diethylether and dried in vaccuo. Triphenylphosphine ligands are easily replaced by other ligands in the precursor complexes [19]. The complexes of general formula $\left[\mathrm{Ru}\left(\mathrm{PPh}_{3}\right)_{2}(\mathrm{BZM})_{2} \mathrm{Cl}_{2}\right]$ were synthesized by the reaction of ruthenium dichlorotetratriphenylphosphine with different substituted benzimidazole in 1:2 molar ratio in methanol. Further, $\mathrm{RuCl}_{2}\left(\mathrm{pph}_{3}\right)_{4}(0.265 \mathrm{~g}, 1 \mathrm{mmol})$ was added to a methanolic solution of the ligands, $2 \mathrm{mmol}$ (LS1, 0.328g; LS2, 0.554 g; LS3, 0.478 g; LS4, 0.146 g; LS5, 0.456 g). The solutions were refluxed for $10 \mathrm{~h}$ in nitrogen and reduced the volume, thus a microcrystalline precipitate was obtained (Scheme-I). The analytical data for these complexes are in good agreement with their respective molecular formula. The new complexes were formed by the substitution of two triphenyl phosphine complexes by benzimidazole which indicates the labile nature of phosphine bond and addition of Nitrogen based ligands, this is due to the better sigma $(\sigma)$ donating ability of the nitrogen bases to that of triphenylphosphine [20]. The complexes were sparingly soluble in organic solvent as acetone, alcohol and methanol but soluble in DMSO/DMF. The molar conductivities values were $0.055-0.163 \mathrm{ohm}^{-1} \mathrm{~cm}^{2} \mathrm{~mol}^{-1}$. The observed values indicates the non-electrolytic nature of complexes.

$\left[\mathbf{R u}\left(\mathbf{P P h}_{3}\right)_{2}(\mathbf{L S 1})_{2} \mathbf{C l}_{2}\right] \cdot \mathbf{3 H}_{2} \mathrm{O}$ (MLS1): Dark brown colour, yield: $46 \%$; m.p.: $327^{\circ} \mathrm{C}$, IR (KBr, $\left.v_{\max }, \mathrm{cm}^{-1}\right)$ : $1143(\mathrm{P}-\mathrm{Ph})$, $1328 v(-\mathrm{NH}), 2963(\mathrm{NH}),{ }^{1} \mathrm{H}$ NMR (300 MHz, DMSO- $d_{6}, \delta$ ppm): $\delta 6.80$ (m, $\left.\mathrm{PPh}_{3}\right), 7.01-7.66(\mathrm{~m}, 4 \mathrm{H}, \mathrm{Ar}-\mathrm{H}), 4.01$ (s, $1 \mathrm{H}$, $\mathrm{NH}), 2.40\left(2 \mathrm{H}, \mathrm{CH}_{2}\right) ; 2.49$ (s, $\left.1 \mathrm{H}, \mathrm{sh}\right) ;{ }^{13} \mathrm{C} \mathrm{NMR}(300 \mathrm{MHz}$, DMSO- $d_{6}, \delta$ ppm): $\delta 135,122$; MS (ESI) $m / z: 1077$ (1076). Anal. calcd. (found) (\%) $\mathrm{RuP}_{2} \mathrm{C}_{12} \mathrm{C}_{52} \mathrm{H}_{52} \mathrm{~N}_{4} \mathrm{~S}_{2} \mathrm{O}_{3}$ : C, 57.09 (57.09); H, 4.83 (4.83); N, 5.20 (4.80). ${ }^{31} \mathrm{P}$ NMR (500 MHz, DMSO- $d_{6}, \delta$ ppm): $\delta 40.34 \mathrm{ppm}\left(\mathrm{s}, \mathrm{PPh}_{3}\right)$. UV-Vis (DMSO, $\lambda_{\max }, \mathrm{nm}\left(\varepsilon_{\max } \times\right.$ $10^{3} \mathrm{M}^{-1} \mathrm{~cm}^{-1}$ ): 240 (3.5), 260 (3.2), 450 (1.0).

[Ru( $\left.\left.\mathbf{R P h})_{3}\right)_{2} \mathbf{C l}_{2}(\mathbf{L S 2})_{2}\right]$ (MLS2): Dark red colour: yield: $62 \%$; m.p.: $296^{\circ} \mathrm{C}, \mathrm{IR}\left(\mathrm{KBr}, v_{\max }, \mathrm{cm}^{-1}\right)$ : $1156(\mathrm{P}-\mathrm{Ph}), 1371\left(\mathrm{NH}_{2}\right)$, $3056\left(\mathrm{NH}_{2}\right.$ str. $),{ }^{1} \mathrm{H}$ NMR $\left(300 \mathrm{MHz}, \mathrm{DMSO}-d_{6}, \delta \mathrm{ppm}\right): \delta 6.67$ $\left(\mathrm{s}, \mathrm{PPh}_{3}\right), 7.26-7.66(\mathrm{~m}, 8 \mathrm{H}, \mathrm{Ar}-\mathrm{H}), 6.60(2 \mathrm{H}, \mathrm{NH}), 1.25-3.79$ $\left(\mathrm{m}, 16 \mathrm{H}, \mathrm{CH}_{2}\right) .{ }^{13} \mathrm{C}$ NMR (300 MHz, DMSO- $\left.d_{6}, \delta \mathrm{ppm}\right): \delta 134$, 133, 132, 131, 129, 128. ESI-MS m/z: 1177 (1178). Anal. calcd. (found) (\%) $\mathrm{RuP}_{2} \mathrm{Cl}_{2} \mathrm{C}_{56} \mathrm{H}_{56} \mathrm{~N}_{4} \mathrm{Br}_{2}$ : C, 57.09 (56.59); $\mathrm{H}, 4.75$ (4.25); N, 4.75 (4.55). ${ }^{31} \mathrm{P}$ NMR (500 MHz, DMSO- $\left.d_{6}, \delta \mathrm{ppm}\right)$ : $\delta$ 40.38. UV-Vis (DMSO, $\lambda_{\max }, \mathrm{nm}\left(\varepsilon_{\max } \times 10^{3} \mathrm{M}^{-1} \mathrm{~cm}^{-1}\right): 240$ (2.53), $260(0.6), 450(1.0)$.

$\left[\mathbf{R u}\left(\mathbf{P P h}_{3}\right)_{2} \mathbf{C l}_{2}(\mathbf{L S 3})_{2}\right] \mathbf{H}_{2} \mathbf{O}$ (MLS3): Brownish, yield: 42 $\%$; m.p.: $320^{\circ} \mathrm{C}, \mathrm{IR}\left(\mathrm{KBr}, v_{\max }, \mathrm{cm}^{-1}\right): 1171(\mathrm{PPh}), 1585(\mathrm{C}=\mathrm{N})$, 
1926 (NO), ${ }^{1} \mathrm{HNMR}\left(300 \mathrm{MHz}, \mathrm{DMSO}-d_{6}, \delta \mathrm{ppm}\right): 6.90\left(\mathrm{~s}, \mathrm{PPh}_{3}\right)$, 7.56-8.26 (16H, Ar-H), $6.60(2 \mathrm{H}, \mathrm{NH}) .{ }^{13} \mathrm{C}$ NMR $(300 \mathrm{MHz}$, DMSO- $d_{6}, \delta$ ppm): $166,150,145,141,138,136,131,127$, 127, 124, 101. ESI-MS m/z: 1191 (1192). Anal. calcd. (found) (\%) $\mathrm{RuP}_{2} \mathrm{Cl}_{2} \mathrm{C}_{62} \mathrm{H}_{50} \mathrm{~N}_{6} \mathrm{O}_{5}: \mathrm{C}, 62.46$ (62.92); H, 4.19 (4.16); $\mathrm{N}$, 7.16 (6.66). ${ }^{31} \mathrm{P}$ NMR (500 MHz, DMSO- $d_{6}, \delta \mathrm{ppm}$ ): $\delta 40.53$. UV-Vis (DMSO, $\lambda_{\max }, \mathrm{nm}\left(\varepsilon_{\max } \times 10^{3} \mathrm{M}^{-1} \mathrm{~cm}^{-1}\right): 220$ (2.6), 260 (2.65), 275 (2.4), 350 (1.8), 450 (0.5).

$\left[\mathbf{R u}\left(\mathbf{P P h}_{3}\right)_{2}(\mathbf{L S 4})_{2} \mathbf{C l}_{2}\right] \cdot \mathbf{H}_{2} \mathbf{O}$ (MLS4): Black, yield: $42 \%$, m.p.: $308{ }^{\circ} \mathrm{C}$, IR ( $\left.\mathrm{KBr}, v_{\max }, \mathrm{cm}^{-1}\right)$ : $1199(\mathrm{P}-\mathrm{Ph}), 1320\left(\mathrm{NH}_{2}\right)$, $3700\left(\mathrm{NH}_{2}\right.$ str.), ${ }^{1} \mathrm{H}$ NMR (300 MHz, DMSO- $d_{6}, \delta$ ppm): 7.13 (m, $\left.\mathrm{PPh}_{3}\right), 7.28-8.04(\mathrm{~m}, \mathrm{ArH}), 6.80(\mathrm{~s}, \mathrm{NH}),{ }^{13} \mathrm{C} \mathrm{NMR}(300 \mathrm{MHz}$, DMSO- $d_{6}, \delta$ ppm): $168,137,135,133,132,131,129,128,121$, ESI-MS m/z: 1099 (1100). Anal. calcd. (found) (\%) $\mathrm{RuP}_{2} \mathrm{Cl}_{2} \mathrm{C}_{62}$ $\mathrm{H}_{50} \mathrm{~N}_{4} \mathrm{O}$ : C, 67.69 (67.09); H, 4.54 (4.04); N, $0.36(0.26) .{ }^{31} \mathrm{P}$ NMR (500 MHz, DMSO- $d_{6}, \delta$ ppm): 40.54, UV-Vis (DMSO, $\lambda_{\max }, \mathrm{nm}\left(\varepsilon_{\max } \times 10^{3} \mathrm{M}^{-1} \mathrm{~cm}^{-1}\right): 240(2.5), 255(0.6), 450(0.5)$, $550(0.8)$.

$\left[\mathbf{R u}\left(\mathbf{P P h}_{3}\right)_{2}(\mathbf{L S 5})_{2} \mathbf{C l}_{2}\right] \cdot \mathbf{2} \mathbf{H}_{2} \mathrm{O}$ (MLS5): Black crystalline colour: yield: $38 \%$, m.p.: $348^{\circ} \mathrm{C}$, IR $\left(\mathrm{KBr}, v_{\max }, \mathrm{cm}^{-1}\right): 1186$ (P$\mathrm{Ph}), 1314\left(\mathrm{NH}_{2}\right), 3300\left(\mathrm{NH}_{2}\right.$ str. $) ;{ }^{1} \mathrm{H}$ NMR $(300 \mathrm{MHz}$, DMSO$\left.d_{6}, \delta \mathrm{ppm}\right): 6.91\left(\mathrm{~m}, \mathrm{PPh}_{3}\right), 7.54-7.90(\mathrm{~m}, \mathrm{ArH}), 2.50(\mathrm{~s}, 2 \mathrm{H}$, $\left.\mathrm{NH}_{2}\right), 6.42$ (s, H, NH), ${ }^{13} \mathrm{C}$ NMR $\left(300 \mathrm{MHz}\right.$, DMSO- $\left.d_{6}, \delta \mathrm{ppm}\right)$ : 144, 142, 139, 127, 101. ESI-MS m/z: 1149 (1151). Anal. calcd. (found) (\%): C, 64.75 (64.25); H, 4.87 (4.07); N, 7.31 (7.01). ${ }^{31} \mathrm{P}$ NMR (500 MHz, DMSO- $\left.d_{6}, \delta \mathrm{ppm}\right): 40.58$. UV-Vis (DMSO, $\lambda_{\max }, \mathrm{nm}\left(\varepsilon_{\max } \times 10^{3} \mathrm{M}^{-1} \mathrm{~cm}^{-1}\right): 250$ (3.3), 405 (2.3), 460 (1.5).

Computational details: The Gaussion- 09 program package was used to perform density functional theory (DFT) calculations [21]. The gas phase geometry of complexes were fully optimized using B3LYP hybrid functional using 6-31G** basis set for all the atoms expect Ru. For Ru, LANL2DZ basis set was used $[22,23]$.

\section{RESULTS AND DISCUSSION}

Infrared studies: Infrared spectra of the ligands showed the characteristic band at $1600-1450$ and $3600-3100 \mathrm{~cm}^{-1}$ which corresponds to $v(\mathrm{C}=\mathrm{N})$ and $v(\mathrm{~N}-\mathrm{H})$ for LS1-LS5. The vibrational spectra of the metal complexes were compared with the corresponding ligands to study the binding behaviour of ruthenium metal to the ligand. The band position of metal complexes at $3145 \mathrm{~cm}^{-1}$ was observed in all the cases which could be assigned to $v(\mathrm{~N}-\mathrm{H})$ of benzimidazole. This feature suggested that the group $\mathrm{NH}$ is not coordinated nor deprotonated during complex formation. Though, there was shift in $v(\mathrm{C}=\mathrm{N})$ in the spectra of the complexes containing benzimidazole, suggests coordination of ruthenium metal ion through nitrogen. Further, in all complexes, band position in the range 1199-1143 of $\mathrm{M}^{-\mathrm{PPh}_{3}}$ suggests the coordination of metal-phosphorus [24].

NMR studies: The ${ }^{1} \mathrm{H}$ NMR spectra, display aromatic protons in the range, $\delta 8.0-6.0 \mathrm{ppm}$ in all complexes and there integration indicates the coordination of two benzimidazole moiety. In MLS1, two multiplet in the range $\delta$ 7.23-7.26 and proton signals at $\delta 6.52(4 \mathrm{H})$ and singlet at $\delta 4.0(2 \mathrm{H})$ indicated the presence of amino phenyl group. In MLS2, ${ }^{1} \mathrm{H}$ NMR spectrum showed a singlet at $\delta 1.5(2 \mathrm{H})$ and $\delta 3.82(3 \mathrm{H})$ protons confirmed the presence of methane thiol group. In MLS3, multiplet at $\delta$ 3.12 for one proton and doublet at $\delta 1.29$ for six protons indicate the presence of propane group. In case of MLS4, two multiplets at $\delta 8.25$ and $\delta 7.74$ for two protons indicated the substitution of nitro phenyl at $\mathrm{C} 2$ of benzimidazole nucleus. One weak singlet at $\delta 12.40$ may be assigned to the $\mathrm{N}-\mathrm{H}$ proton of benzimidazole.

${ }^{31} \mathrm{P}$ spectra of all the ruthenium(II) complexes were recorded in DMSO- $d_{6}$ in order to confirm the presence of triphenyl phosphine groups and to determine the geometry of the complexes. The observation of sharp singlet peak in the range $\delta 7.50$ 6.40 , suggest the only one possible geometric isomer of the complexes is formed [25]. However, IR spectrum showed single absorption band around $1199-1143 \mathrm{~cm}^{-1}$, suggests that triphenyphosphine is in trans-position [26].

Electronic absorption spectroscopy: The UV-visible absorption spectral assignments of complexes are presented in Table1. The intense high energy band below $300 \mathrm{~nm}$ is assigned to ligand centered transitions. The low energy absorptions at 600 $\mathrm{nm}$ arise due to Ru based MLCT transitions. The nature of the observed electronic spectra and the positions of absorption band are consistent with those of other similar octahedral $\mathrm{Ru}$ (II) complexes [27]. Further, all ruthenium complexes are found to be diamagnetic which suggest that their geometry ought to be octahedral as revealed by geometry optimization. The absorption band in the range $220-450 \mathrm{~nm}$, based on the values of extinction coefficient (2.2-0.50) both band assigned to $\pi-\pi^{*}$ transitions arising from an excitation of an intra ligand orbitals.

TABLE-1

UV-VISIBLE SPECTRAL DATA OF THE LIGANDS AND Ru(II) COMPLEXES IN METHANOL

\begin{tabular}{ll}
\hline Compounds & \multicolumn{1}{c}{$\Lambda_{\max }(\mathrm{nm})\left(\varepsilon_{\max } \times 10^{3} \mathrm{M}^{-1} \mathrm{~cm}^{-1}\right)$} \\
\hline LS1 & $244(0.17), 230(0.34), 2390.61), 250(1.05), 258(1.14), 260(1.15), 265(1.12), 270(1.10), 277(1.10), 280(1.09), 283(0.01)$ \\
LS2 & $213(1.45), 244(1.42), 251(1.66), 267(1.69), 279(1.42), 293(0.14), 3469(0.01), 441(0.52)$ \\
LS3 & $236(1.92), 241(2.02), 249(2.28), 258(2.39), 265(2.29), 281(2.31), 291(2.43), 295(2.36), 326(0.26), 341(0.19), 347(0.17)$ \\
LS4 & $212(0.72), 230(0.73), 240(1.51), 253(1.42), 267(1.37), 273(1.48), 275(1.11), 279(1.18)$ \\
LS5 & $227(1.79), 231(1.92), 243(2.23), 247(2.38), 252(2.48), 260(2.42) 265(2.43), 269(2.38), 280(2.41), 299(2.53), 310(2.20)$, \\
& $332(2.20), 429(0.63)$ \\
MLS1 & $213(1.15), 223(1.60), 230(2.04), 234(2.15), 250(2.50), 257(2.90), 272(2.96), 279(2.90), 301,339(1.50), 350(2.15), 359$ \\
MLS2 & $(2.00), 363(0.75), 399(0.59)$ \\
MLS3 & $209(0.39), 221(0.29), 229(0.30), 259(0.53), 277(0.33), 300(0.22), 340(0.12), 400(0.17), 420(0.20), 460(0.20), 500(0.06)$ \\
MLS4 & $601(0.35), 652(0.25), 703(0.16), 223(2.03), 226(2.13), 238(1.30), 255(0.75), 268(0.76), 287(0.45), 449(0.35), 540(0.51)$, \\
MLS5 & $212(0.73), 230(0.78), 240(1.49), 250(1.49), 267(1.37), 273(1.50), 324,357,372$ \\
& $215(2.20), 223(2.36), 230(2.64), 248(2.67), 256(2.90), 263(2.07), 273(2.96), 281(3.01), 294(3.01), 309(1.96), 338(2.11)$, \\
& $350(2.15), 354(2.27), 359(2.59), 363(2.00), 369(1.93), 399(0.75), 448(0.58)$ \\
\hline
\end{tabular}


The electronic absorption spectra of $\left[\mathrm{Ru}\left(\mathrm{PPh}_{3}\right)_{2}(\mathrm{BZM})_{2} \mathrm{Cl}_{2}\right]$ in methanol generally showed two absorption bands in 550 to $450 \mathrm{~nm}$ range with $\varepsilon$ of the order $10^{3}$. The band around 550 $\mathrm{nm}$ in MLS4 is weaker than that around $450 \mathrm{~nm}$. The band around $550 \mathrm{~nm}$ may have some MLCT character and also certain amount of $d$ - $d$ character.

$\mathrm{X}$-ray diffraction studies: Structural studies were carried out by powder X-ray diffraction using a $1.4 \mathrm{~kW} \mathrm{Cu-rotating}$ anode based Rigaku (Tokyo, Japan) powder diffractometer operating in Bragg-Brentano geometry and fitted with a curved crystal graphite monochromator in the diffraction beam and a high temperature attachment. The XRD data in the $2 \theta$ range of $20-80^{\circ}$ at a step of $0.02^{\circ}$ were collected at room temperature. Fig. 1 depicts the XRD patterns of samples MLS1, MLS2, MLS3, MLS4 and MLS5. It is evident that samples MLS1, MLS2 and MLS5 are stabilized in the crystalline form at room temperature. However samples MLS3, MLS4 are most like amorphous in nature as no sharp Bragg's peaks were observed. In order to investigate the crystal structure of the samples MLS1, MLS2 and MLS3, Lebail profile fittings were carried out using FULLPROF package [28]. In present profile fittings, pseudo-Voigt function and a sixth order polynomial were used

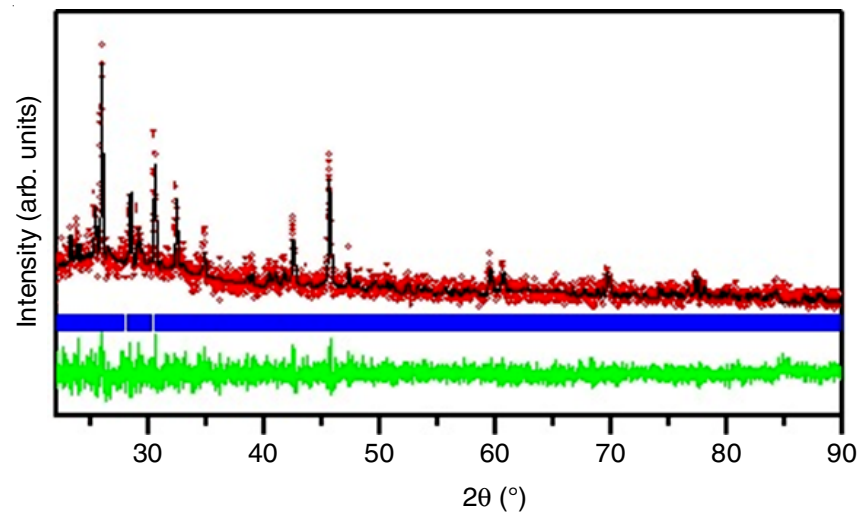

Fig. 1. X-Ray diffraction pattern of metal complex

to define the profile shape and background, respectively. During the profile fittings, parameters, such as the scale factor, zero correction, background, half-width parameters, the mixing parameters, lattice were varied. Table- 2 depicts the observed, calculated and difference profiles obtained after the Lebail analysis of the full XRD pattern for MLS2 using monoclinic space group P21/c. The fit between the observed and calculated profiles is quite good suggest that the sample MLS5 most likely
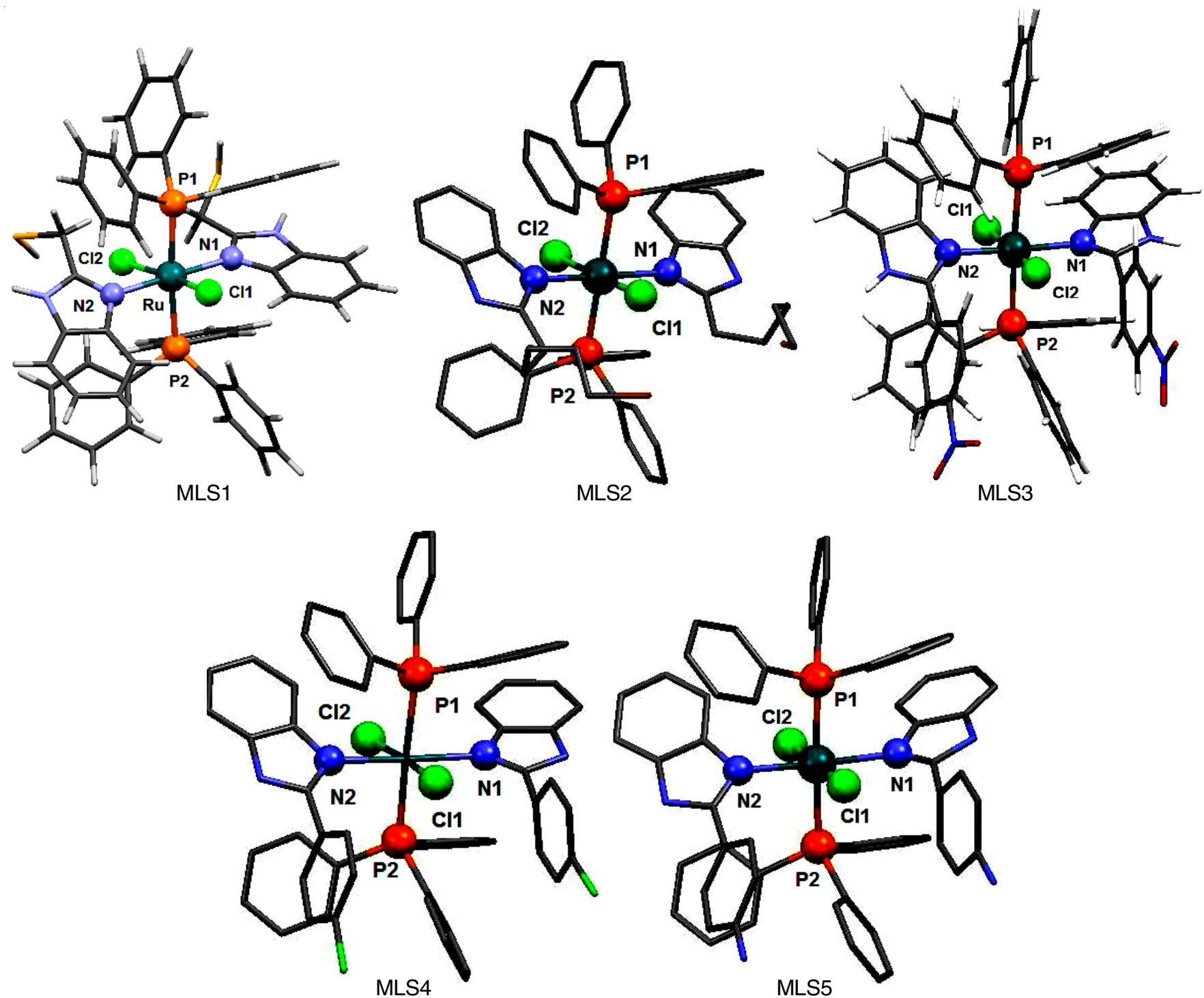

Fig. 2. Perspective view of optimized geometry of metal complexes 


\begin{tabular}{ccccccc}
\hline & \multicolumn{5}{c}{ TABLE-2 } \\
& \multicolumn{4}{c}{ UNIT CELL PARAMETER OBTAINED AFTER PROFILE FITTING OF X-RAY DIFFRACTION } \\
& \multicolumn{1}{c}{ DATA COLLECTED AT ROOM TEMPERATURE USING MONOCLINIC SPACE GROUP p21/c } \\
\hline Sample & $\mathrm{a}(\AA)$ & $\mathrm{b}(\AA)$ & $\mathrm{c}(\AA)$ & $\alpha\left(^{\circ}\right)$ & $\beta\left(^{\circ}\right)$ & $\gamma\left({ }^{\circ}\right)$ \\
\hline MLS1 & $17.521(2)$ & $21.562(4)$ & $10.719(1)$ & 90.00 & $91.05(1)$ & 90.00 \\
MLS2 & $17.996(3)$ & $22.086(5)$ & $11.0178(2)$ & 90.00 & $90.94(2)$ & 90.00 \\
MLS3 & $18.010(2)$ & $22.076(3)$ & $10.978(3)$ & 90.00 & $91.01(1)$ & 90.00 \\
\hline
\end{tabular}

stabilized in the monoclinic phase at room temperature with space group P21/c symmetry. The unit cell parameters obtained after the Lebail profile fittings for the samples MLS1, MLS2 and MLS3 are given in Table-2.

Optimized geometry of complexes: In order to gain structural insight regarding the synthesized $\mathrm{Ru}$ (II) complexes, density functional theory (DFT) calculations were performed using suitable functional (vide infra). Perspective views of optimized geometry of these complexes have been presented in Fig. 2. The relevant optimized geometrical parameters of these complexes are comparable with the analogues $\mathrm{Ru}(\mathrm{II})$ complexes [19,29-32]. The geometry optimization results indicate that in all of the complexes, $\mathrm{Ru}$ (II) centre acquires the octahedral geometry. The peculiar feature that is being observed in all the optimized geometry is that two $\mathrm{PPh}_{3}$ moieties adopts trans-position with respect to each other. This can be attributed to the inherent bulkiness associated with the $\mathrm{PPh}_{3}$ ligand and also because of the relatively strong trans directing influence by chloro ligands [19]. The pertinent optimized geometrical parameters for the $\mathrm{Ru}(\mathrm{II})$ complexes is shown in Table- 3 .

\begin{tabular}{lccccc}
\multicolumn{7}{c}{ TABLE-3 } \\
\multicolumn{5}{c}{ OPTIMIZED GEOMETRICAL PARAMETERS FOR Ru(II) } \\
\multicolumn{6}{c}{ COMPLEXES [BOND LENGTH $(\AA)$ AND BOND ANGLE $\left(^{\circ}\right)$ ] } \\
\hline Parameter & MLS1 & MLS2 & MLS3 & MLS4 & MLS5 \\
\hline Ru-N1 & 2.230 & 2.319 & 2.330 & 2.268 & 2.314 \\
Ru-N2 & 2.307 & 2.257 & 2.261 & 2.322 & 2.258 \\
Ru-P1 & 2.529 & 2.515 & 2.511 & 2.552 & 2.551 \\
Ru-P2 & 2.513 & 2.562 & 2.534 & 2.506 & 2.502 \\
Ru-Cl1 & 2.513 & 2.510 & 2.534 & 2.472 & 2.502 \\
Ru-c12 & 2.541 & 2.543 & 2.473 & 2.539 & 2.427 \\
Ru-N1-C & 126.94 & 125.70 & 125.21 & 123.85 & 125.60 \\
Ru-N2-C & 126.72 & 125.85 & 123.81 & 125.19 & 122.25 \\
Ru-P1-C & 117.92 & 115.44 & 112.30 & 114.37 & 110.88 \\
Ru-P2-C & 122.52 & 124.21 & 123.07 & 117.53 & 123.61 \\
P1-Ru-P2 & 174.45 & 177.53 & 176.40 & 176.19 & 177.42 \\
Cl1-Ru-Cl2 & 170.63 & 176.78 & 175.47 & 175.21 & 177.57 \\
\hline
\end{tabular}

Morphological cytotoxicity study: The morphological changes in HeLa cells were observed under inverted phase contrast microscope after treatment of MR, MLS2 and LS1 at $10,25,50,100$ and $200 \mu \mathrm{M}$ concentrations for $24 \mathrm{~h}$. As depicted in Fig. 3, severe changes were observed in the morphology of HeLa cells treated with MR, MLS2 and LS1. The treated cells showed a typical feature of apoptosis viz. cytoplasmic vacuolization, cellular shrinkage, became round shape and nuclear condensation as compared to the untreated cells which were also reported by an earlier study [33]. While the untreated control cells exhibit even cell surface, flat and remained smooth, signifying the morphology of healthy cells.

Nuclear condensation and apoptosis: Induction of apoptosis in cancerous cells is considered as a valuable method to cure the various cancers. Apoptosis is usually characterized by

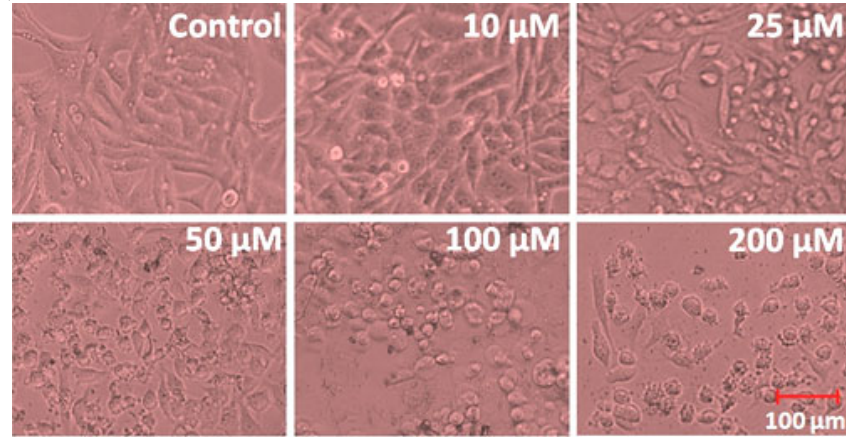

(A) MR
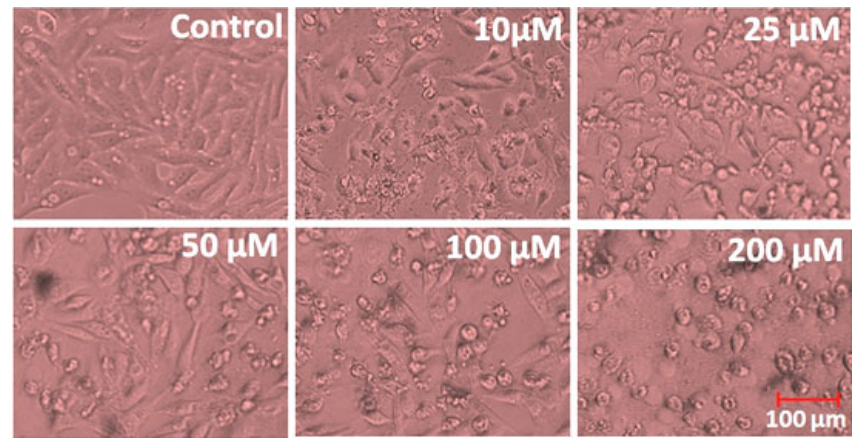

(b) MLS2
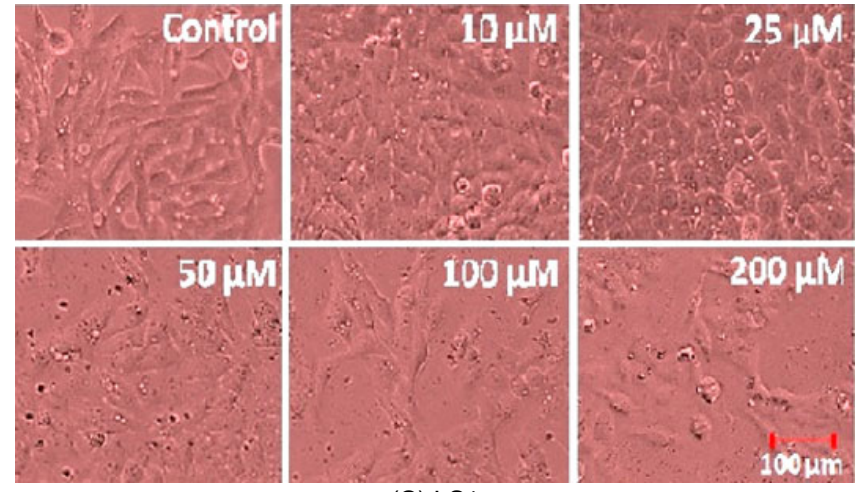

(C) LS1

Fig. 3. Photomicrograph showing morphological changes in HeLa cells after treatment with 10, 25, 50, 100 and $200 \mu \mathrm{M}$ concentrations of (A)MR (B)MLS2 and (C) LS1, at $24 \mathrm{~h}$ by inverted phase contrast microscopy

the typical morphological and biological changes in cells like shrinkage of the cell, condensation of nuclear chromatin and fragmented apoptotic bodies [34]. In this study, we observed concentration dependent nuclear apoptosis in HeLa cells in MR, MLS2 and LS1. As evident from photomicrographs of HeLa cells (Fig. 4), synthesized compounds exhibit apoptosis in HeLa cells evident by the occurrence of chromatin condensation and nuclear bounded apoptotic bodies. As evident from the pictorial graph representing quantitative $\%$ apoptotic cells at 25,50 and $100 \mu \mathrm{M}$ of MR showed approximately 9.39, 16.347 and $23.34 \%$ of apoptotic cells in HeLa cells. Furthermore, at 

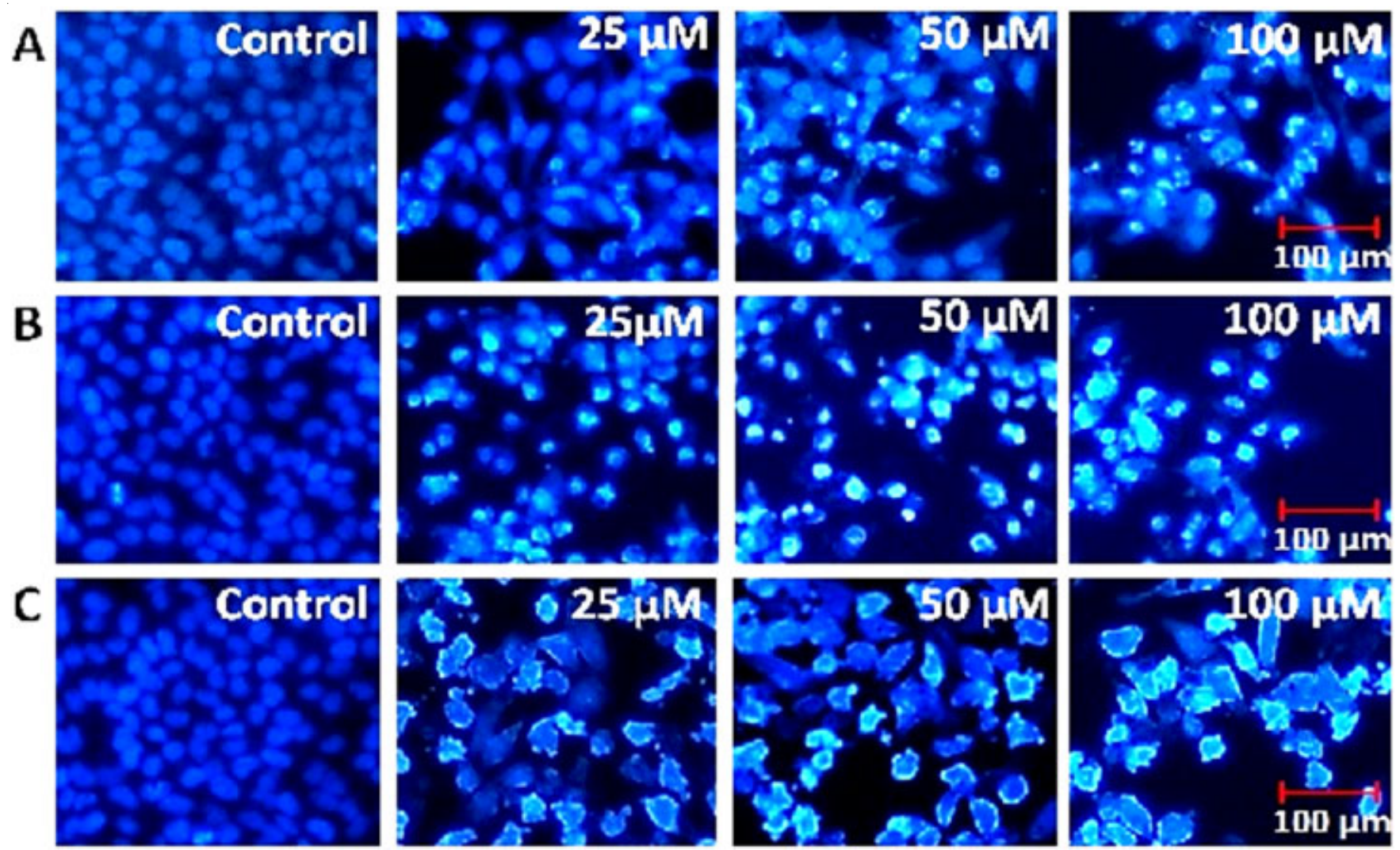

Fig. 4. Photomicrograph showing morphological changes, nuclear condensation and cellular apoptosis on HeLa cells, treated with 25,50 and $100 \mu \mathrm{M}$ of MR, MLS2 and LS1 against HeLa cells

25, 50 and $100 \mu \mathrm{M}$ doses of MLS2, showed around 14.34, 21.85 and $30.67 \%$ of apoptotic cells and LS1 showed approximately $6.67,12.34$ and $20.85 \%$ apoptotic cells with respect to control (Fig. 5). The photomicrograph of HeLa cells having condensed and fragmented nuclei suggest that MR, MLS2 and LS1 induced the cell death by the process of apoptotic. The anti-proliferative effects of MR, MLS2 and LS1 on HeLa cells were inspected using the MTT assay after $24 \mathrm{~h}$ exposure. As revealed from Fig. 6, data of cell viability on HeLa cells displayed that MR at $10,25,50,100$ and $200 \mu \mathrm{M}$ concentrations significantly reduced the viability $92.01,79.18,63.99,52.31$ and $39.18 \%$ $(\mathrm{p}<0.001)$ respectively, as compared to untreated cells (taken as $100 \%$ viable). Likewise at $10,25,50,100$ and $200 \mu \mathrm{M}$ doses

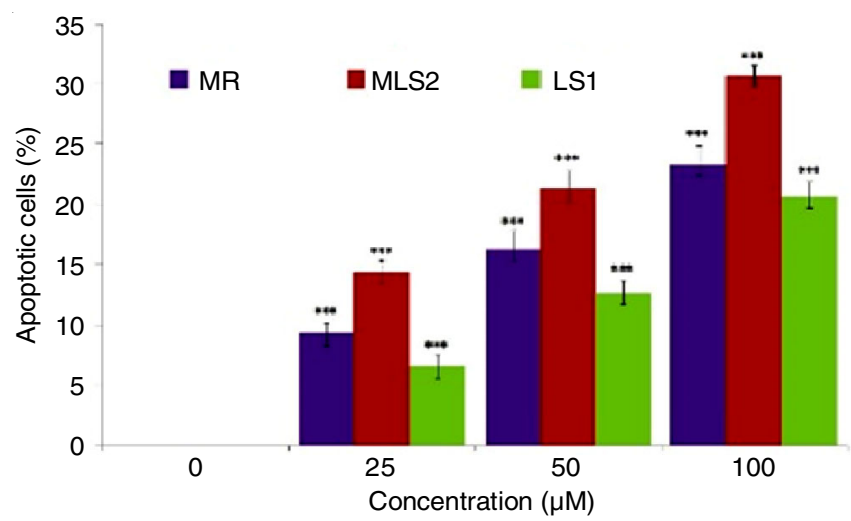

Fig. 5. Column graph representing \% apoptotic cells in HeLa cells at 25, 50 and $100 \mu \mathrm{M}$ concentrations of MR, MLS2 and LS1. Data were represented as mean \pm SEM of three independent experiments and value of $\mathrm{p}^{* * *} \leq 0.001$

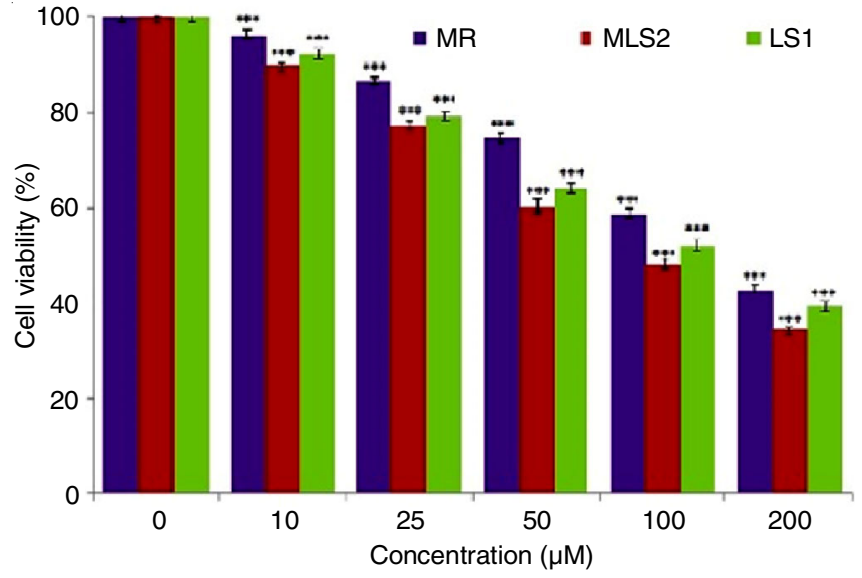

Fig. 6. Column graph demonstrating as the \% cell viability at different concentrations of MR, MLS2 and LS1on HeLa cells, calculated by MTT assay after $24 \mathrm{~h}$ incubation. Data are represented as mean \pm SEM of three independent experiments and value of $\mathrm{p}^{* * *} \leq 0.001$

of MLS2 treatment reduced the cell viability in 89.43, 77.01, $60.00,47.87$ and $34.37 \%$, while LS1 showed approximately $96.21,86.38,74.40,58.87$ and $42.79 \%(\mathrm{p}<0.001)$ reduction of viable cells, with respect to the control. The results clearly recommended that MR, MLS2 and LS1 significantly reduced the viability of cervical carcinoma cell line depending upon dose. The IC $_{50}$ value of MR, MLS2 and LS1 against HeLa cells was estimated to be $90.8,81.8$ and $115 \mu \mathrm{g} / \mathrm{mL}$, respectively and suggested that MLS2 was found to be more toxic as compared to MR and LS1. This study also supported the previous report that metal complexes were more toxic than that of ligand [35]. 
Intracellular ROS generation: The apoptosis is characterized by drastic alterations in expression and action of some potent apoptotic markers [36]. ROS production has also been involved in an initial incident of the cellular apoptosis and various cancer chemotherapeutic drugs induce apoptosis by induction of ROS [36]. Present result also supports the ROSmediated cellular apoptosis in HeLa cells with the increasing concentrations of MR, MLS2 and LS1 as compared to untreated cells (Fig. 4). Similarly, the results obtained from the quantitative fluorescence intensities showed that $25 \mu \mathrm{M}$ concentration of MR, MLS2 and LS1 induced ROS production approximately $119.56,125.19$ and $108.95 \%(* * * \mathrm{p}<0.001)$, respectively as compared to control. At $50 \mu \mathrm{M}$ concentration of MR, MLS2 and LS1 increased by nearly $127.67,140.48$ and $119.38 \%$ $(* * * \mathrm{p}<0.001)$, respectively, whereas the maximum ROS level approximately $147.07,167.79$ and $135.21 \%(* * * p<0.001)$, were observed at the concentrations of $100 \mu \mathrm{M}$ when compared to untreated cells (Fig. 7). As depicted from the result of DCF fluorescence the compound MLS2 found to be more toxic with respect to MR and LS1. The conclusion of present study provides a supportive molecular mechanism of cellular apoptosis of the tested MR, MLS2 and LS1.

\section{Conclusion}

The cellular apoptosis by MTT assay proposed that MR, MLS2 and LS1 significantly reduced the viability of HeLa cells in a dose-dependent manner. The inhibitory concentration $\left(\mathrm{IC}_{50}\right)$ value of MR, MLS2 and LS1 was estimated to be 90.8, 81.8 and $115 \mu \mathrm{g} / \mathrm{mL}$ for HeLa cells, respectively. The excessive ROS generation supports the molecular mechanism of apoptosis as well as the data of nuclear condensation assay, also suggested that these synthesised compound induced cell death in HeLa cells by an apoptotic manner.

\section{ACKNOWLEDGEMENTS}

The authors gratefully acknowledge Rajiv Gandhi National Fellowship for financial Support and DST-PURSE, Department of Chemistry, Lucknow University, Lucknow, India.

\section{CONFLICT OF INTEREST}

The authors declare that there is no conflict of interests regarding the publication of this article.

\section{REFERENCES}

1. B. Rosenberg, L. Van Camp, J.E. Trosko and V.H. Mansour, Nature, 222, 385 (1969);

https://doi.org/10.1038/222385a0.

2. $\quad$ L. Kelland, Nat. Rev. Cancer, 7, 573 (2007);

https://doi.org/10.1038/nrc2167.

3. S. Medici, M. Peana, V.M. Nurchi, J.I. Lachowicz, G. Crisponi and M.A. Zoroddu, Coord. Chem. Rev., 284, 329 (2015);

https://doi.org/10.1016/j.ccr.2014.08.002.

4. A. Bergamo, C. Gaiddon, J.H. Schellens, J.H. Beijnen and G. Sava, J. Inorg. Biochem., 106, 90 (2012); https://doi.org/10.1016/j.jinorgbio.2011.09.030.

5. J.M. Rademaker-Lakhai, D. van den Bongard Pluim, J.H. Beijnen and J.H.M. Schellens, Clin Cancer Res., 10, 3717 (2004); https://doi.org/10.1158/1078-0432.CCR-03-0746.

6. M. Brindell, I. Stawoska, J. Supel, A. Skoczowski, G. Stochel and R. van Eldik, J. Biol. Inorg. Chem., 13, 909 (2008); https://doi.org/10.1007/s00775-008-0378-3.
7. C.G. Hartinger, S. Zorbas-Seifried, M.A. Jakupec, B. Kynast, H. Zorbas and B.K. Keppler, J. Inorg. Biochem., 100, 891 (2006);

https://doi.org/10.1016/j.jinorgbio.2006.02.013.

8. A.K. Singh, G. Saxena, Sahabjada and M. Arshad, Specrochim. Acta A: Mol. Biomol. Spectrsc., 180, 97 (2017); https://doi.org/10.1016/j.saa.2017.02.056.

9. A.K. Singh, G. Saxena, S. Dixit, S.K. Hamidullah, S.K. Singh, S.K. Singh, M. Arshad and R. Konwar, J. Mol. Struct., 1111, 90 (2016); https://doi.org/10.1016/j.molstruc.2016.01.070.

10. A.H. Cory, T.C. Owen, J.A. Barltrop and J.G. Cory, Cancer Commun., 3, 207 (1991); https://doi.org/10.3727/095535491820873191.

11. P.J. Dyson, Chimia, 61, 698 (2007); https://doi.org/10.2533/chimia.2007.698.

12. R. Palchaudhuri and P.J. Hergenrother, Curr. Opin. Biotechnol., 18, 497 (2007); https://doi.org/10.1016/j.copbio.2007.09.006.

13. G. Stochel, A. Wanat, E. Kulis and Z. Stasicka, Coord. Chem. Rev., 171, 203 (1998); https://doi.org/10.1016/S0010-8545(98)90033-9.

14. H. Miki, N. Uehara, A. Kimura, T. Sasaki, T. Yuri, K. Yoshizawa and A. Tsubura, Int. J. Oncol., 40, 1020 (2012); https://doi.org/10.3892/ijo.2012.1325.

15. T.M. Li, G.W. Chen, C.C. Su, J.G. Lin, C.C. Yeh, K.C. Cheng and J.G. Chung, Anticancer Res., 25, 971 (2005).

16. S. Siddiqui, E. Ahmad, M. Gupta, V. Rawat, N. Shivnath, M. Banerjee, M.S. Khan and M. Arshad, Cell Prolif., 48, 443 (2015); qhttps://doi.org/10.1111/cpr.12195.

17. R.K. Singh, A.K. Singh, S. Siddiqui, M. Arshad and A. Jafri, J. Mol. Struct., 1135, 82 (2017); https://doi.org/10.1016/j.molstruc.2017.01.059

18. G. Mariappan, R. Hazarika, F. Alam, R. Karki, U. Patangia and S. Nath, Arab. J. Chem., 8, 715 (2015); https://doi.org/10.1016/j.arabjc.2011.11.008.

19. T.A. Stephenson and G. Wilkinson, J. Inorg. Nucl. Chem., 28, 945 (1966); https://doi.org/10.1016/0022-1902(66)80191-4.

20. P.S. Hallman, T.A. Stephenson and G. Wilkinson, Inorg. Synth., 12, 40 (1970); https://doi.org/10.1002/9780470132432.ch40.

21. S. Sabo-Etienne and M. Gellier, Encyclopedia of Inorganic Chemistry, John Wiley \& Sons (2006).

22. A.D. Becke, J. Chem. Phys., 98, 5648 (1993); https://doi.org/10.1063/1.464913.

23. J.P. Perdew and Y. Wang, Phys. Rev. B, 45, 13244 (1992); https://doi.org/10.1103/PhysRevB.45.13244.

24. A.M. Pyle, J.P. Rehmann, R. Meshoyrer, C.V. Kumar, N.J. Turro and J.K. Barton, J. Am. Chem. Soc., 111, 3051 (1989); https://doi.org/10.1021/ja00190a046.

25. R. Lalrempuia, P.J. Carroll and M.R. Kollipara, J. Coord. Chem., 56, 1499 (2003); https://doi.org/10.1080/00958970310001628957.

26. P. Sengupta, S. Ghosh and T.C.W. Mak, Polyhedron, 20, 975 (2001); https://doi.org/10.1016/S0277-5387(01)00736-7.

27. S.A. Moya, R. López, C. Pérez-Zúñiga, M. Yáñez and P. Aguirre, $J$. Coord. Chem., 68, 2423 (2015); https://doi.org/10.1080/00958972.2015.1047357.

28. R. Karvembu and K. Natarajan, Polyhedron, 21, 1721 (2002); https://doi.org/10.1016/S0277-5387(02)01038-0.

29. J. Rodríguez-Carvajal, Physica B, 192, 55 (1993); https://doi.org/10.1016/0921-4526(93)90108-I.

30. J. Yellol, S.A. Pérez, A. Buceta, G. Yellol, A. Donaire, P. Szumlas, P.J. Bednarski, G. Makhloufi, C. Janiak, A. Espinosa and J. Ruiz, J. Med. Chem., 58, 7310 (2015); https://doi.org/10.1021/acs.jmedchem.5b01194.

31. S. Chowdhury, A. Bhattacharya, P. Saha, S. Majumder, E. Suresh and J.P. Naskar, J. Coord. Chem., 69, 3664 (2016); https://doi.org/10.1080/00958972.2016.1234047.

32. B.J. Coe, M. Helliwell, J. Raftery, S. Sánchez, M.K. Peers and N.S. Scrutton, Dalton Trans., 47, 5210 (2016); https://doi.org/10.1039/C5DT03753K.

33. D. J. Taatjes, B. E. Sobel and R. C. Budd, Histochem. Cell. Biol., 129, 33 (2008).

34. M. Arshad, S. Siddiqui and D. Ali, Caryologia, 69, 128 (2016); https://doi.org/10.1080/00087114.2015.1136542.

35. G.I. Evan and K.H. Vousden, Nature, 411, 342 (2001); https://doi.org/10.1038/35077213.

36. M. Chen, B. Zhou, P. Zhong, V. Rajamanickam, X. Dai, K. Karvannan, H. Zhou, X. Zhang and G. Liang, Prostate, 77, 489 (2017); https://doi.org/10.1002/pros.23287. 